Social Work \& Education

๑) SW\&E, 2019
УДК 371.134: 364

DOI: $10.25128 / 2520-6230.19 .3 .8$
Повідайчик, О. \& Варга, Н. (2019). Науководослідницька підготовка майбутніх фахівців соціальної сфери в університетах США. Social Work and Education. Vol. 6, No. 3. TernopilAberdeen, 2019. pp. 307-315. DOI: 10.25128/25206230.19.3.8

\section{НАУКОВО-ДОСЛЧДНИЦЬКА ПІДГОТОВКА МАЙБУТНІХ ФАХІВЦІВ СОЦІАЛЬНОЇ СФЕРИ В УНIВЕРСИТЕТАХ США}

\section{Оксана Повідайчик,}

доктор педагогічних наук,

дочент кафедри сочуілогії та

соияіальної роботи, ДВНЗ

«Ужсгородський національний

університет»,

м. Уэсгород, Украӥна,

oksana.povidaichyk@uzhnu.edu.ua

\section{Наталія Варга,}

аспірант кафедри загальної педагогіки та педагогіки вищуої школи, ДВНЗ «Ужггородський начіональний університет», м. Ужсгород, Украӥна, varga21051979@gmail.com

Article history:

Received: May 18, 2019

1st Revision: July 22, 2019

Accepted: September 30, 2019
АНОТАЦІЯ. У статті розкрито особливості підготовки фахівців соціальної сфери до науково-дослідницької діяльності у вищій школі США. З'ясовано, що науководослідницька підготовка здійснюється в декількох формах: дослідницькі блоки включаються до складу загальних і профільних навчальних дисциплін; у рамках вивчення спеціалізованих курсів; у процесі розробки проектів 3 дослідницькою спрямованістю; під час практики, обов'язковою складовою якої $\epsilon$ самостійне дослідження. Найбільшого поширення набули такі форми i методи науково-дослідницької підготовки, як: робота 3 випадком, моделювання, навчання в природних умовах, інструктаж, виконання завдань у команді, робота над груповим проектом, ігрові методи.

Ключові слова: професійна підготовка; фахівці соціальної сфери; науководослідницька діяльність; практика; досвід США; форми і методи науково-дослідницької підготовки. 


\section{Вступ}

Одним із факторів ефективного розвитку сучасного суспільства є система освіти, яка на сьогоднішній день знаходиться в процесі реформування. Освіта продукує нові форми і методи соціальних взаємин та зумовлює соціокультурні зміни, адекватні суспільним тенденціям. Актуалізується пошук нових шляхів формування в майбутніх фахівців діяльнісної позиції в процесі навчання, що сприяє становленню досвіду цілісного бачення професійної діяльності, системності під час вирішення певних проблем i завдань. Розширення $\mathrm{i}$ ускладнення соціального досвіду підвищує значущість дослідницької компетентності фахівців соціальної сфери, що зумовлює необхідність інтеграції освітнього процесу і науково-дослідницької діяльності студентів.

\section{Аналіз останніх досліджень і публікацій}

Вивчення джерельної бази засвідчує наявність глибокого інтересу вітчизняних і зарубіжних науковців до проблеми професійної підготовки фахівців соціальної сфери (С. Архипова, О. Безпалько, 3. Бернфельд, О. Вільманн, Г. Вільфінг, М. Доуел, І. Звєрєва, А. Капська, О. Карпенко, Х. Кінтана, І. Козубовська, Г. Лактіонова， І. Ларіонова， Л. Міщик， В. Поліщук， В. Полтавець，Д. Раймонд, Т. Семигіна, С. Харченко, С. Шардлоу). Окремі аспекти науково-дослідницької підготовки студентів у вищій школі вивчають М. Бомбік, Н. Гомеля, Т. Дьячек, Ю. Лавриш， В. Молодиченко, О. Набока, І. Сенча та ін. Світові інтеграційні процеси вимагають вивчення тенденцій розвитку зарубіжних систем освіти, зокрема науково-дослідницької підготовки студентів у вищій школі США, і використання прогресивних ідей у вітчизняному освітньому просторі.

Мета статті - розкрити особливості науково-дослідницької підготовки майбутніх фахівців соціальної сфери в університетах США.

\section{Основна частина}

Однією 3 провідних тенденцій розвитку сучасної освітньої ситуації, що здійснюється на тлі кардинальних змін у соціальній і економічній сферах нашого суспільства, $є$ посилення уваги до формування кадрового потенціалу нового рівня, фахівців, що мають якісну науково-дослідницьку підготовку. Розглянемо особливості цієї підготовки на прикладі спеціальності «Соціальна робота» в університетах США.

Аналіз наукової літератури, навчальних планів i програм факультетів соціальної роботи деяких університетів (штатів Індіана, Юта та ін.) засвідчує, що, незважаючи на однозначне визнання обов'язковості науково-дослідницької підготовки соціальних працівників у вищій школі, на сьогодні немає єдиних підходів щодо іiі організації. В одних університетах практикуються тільки іiі 
окремі елементи, в інших - реалізується ціла система, яка передбачає науководослідницьку підготовку студентів протягом усього періоду навчання. Проте спільною рисою досліджуваного процесу у вищій школі США є раннє залучення студентів до науково-дослідницької діяльності (Ben-David, 2002).

Відповідно до вимог Ради з підготовки соціальних працівників США, у структуру знань про НДД, які повинні мати випускники університету, входять: а) загальнометодологічні і загальнонаукові закони, закономірності та принципи; б) положення науково-пізнавальної діяльності і побудовані на їхній основі методи наукового пошуку; в) принципи і методи досліджень, які застосовуються у різних сферах соціальної практики.

При підготовці соціальних працівників на університетському рівні навчання НДД здійснюється в декількох формах: дослідницькі блоки включаються до складу загальних і профільних навчальних дисциплін; у рамках спеціалізованих курсів, наприклад, «Соціальна статистика», «Дослідження в соціальній роботі» та ін.; у процесі розробки проектів з дослідницькою спрямованістю; дослідницький блок становить обов'язкову частину завдань практики. Завдання, наприклад, формулюються так: «Виділити й описати типові випадки використання методів дослідницької діяльності в роботі 3 клієнтами соціального агентства», «Проаналізувати етично припустимі межі дослідницької діяльності в роботі конкретного агентства», «Спираючись на методи дослідницької діяльності, виявити перспективні напрямки розвитку соціальної роботи 3 певною групою клієнтів» та ін. (Дьячек, 2002).

Повна програма фахової підготовки соціальних працівників включає теоретичний курс і практичне навчання, яке відбувається в соціальних агентствах. Ці дві форми навчання, що виконуються в зовсім різних умовах, сильно відрізняються між собою. Знання та вміння, набуті під час теоретичної підготовки, доповнюються знаннями, здобутими на практиці, i навпаки. Такий процес зумовлює інтеграцію теорії i практики, допомагає сформувати професіонала-дослідника.

Вивчення i аналіз нормативних документів, які регулюють діяльність факультетів соціальної роботи в університетах США, навчальних планів i програм підготовки майбутніх фахівців засвідчує, що в освітніх програмах обов'язковими є п’ять базових дисциплін: «Поведінка людини i соціальне оточення», «Політика і служби соціального забезпечення», «Практика соціальної роботи», «Дослідження в соціальній роботі», «Польова практика».

Чільне місце в навчальному процесі студентів посідає підготовка до досліджень, які передбачають «роботу з випадком» - всебічне вивчення об'єктавипадку, наприклад, людини, сім’, окремого соціуму та ін., тобто фокусування на конкретній соціальній проблемі. Дослідницька акція (робоче дослідження) 
безпосередньо поєднує практику і дослідження, які здійснюються паралельно або одночасно. Навчальними планами факультетів соціальної роботи передбачене виконання незначних дослідницьких проектів, робота над якими будується за індивідуальним або груповим принципом (з використанням супервізорства).

Конкретні знання і досвід організації та проведення досліджень студенти здобувають на заняттях у рамках навчального курсу «Дослідження в соціальній роботі». Він передбачає: знайомство з методологією досліджень, необхідною для визначення проблеми; навчання формулюванню завдань дослідження; роботу 3 науковою і професійною літературою; оволодіння методами дослідження проблеми; розробку дослідницького проекту; ведення записів, здійснення обчислень; ознайомлення 3 процедурою формування вибірок; вивчення методів аналізу даних, інтерпретації результатів дослідження та підготовку звітів про проведену роботу. Програма цього курсу передбачає також навчання студентів написанню рефератів, есе, оглядів (на основі наукової літератури, статей із професійних журналів та ін.), виконання індивідуального або групового дослідницького проекту.

На наш погляд, важливим є те, що як на рівні бакалаврату, так і при підготовці магістрів соціальної роботи зміст курсу «Дослідження в соціальній роботі», вирізняючись глибиною, спектром досліджуваних методів, їхнього математичного забезпечення, передбачає обов'язкове введення студентів як у позитивістські, так і у феноменологічні підходи щодо досліджень. Ми підтримуємо позицію Т. Дьячек щодо ролі і місця двох дослідницьких парадигм у соціальній практиці. Вчена підкреслює, що освоєння ідеології їх обох і практична розробка на їхній основі дослідницьких проектів сприяє формуванню цілісного наукового світогляду майбутніх соціальних працівників, дозволяючи надалі виважено й усвідомлено інтегрувати дослідницьку діяльність у свою практику (Дьячек, 2002).

У програмах професійної підготовки соціальних працівників у США практика становить близько 50\% навчального часу. Її роль у зарубіжних моделях науководослідницької підготовки важко переоцінити. Основне призначення практики полягає в тому, щоб студенту дати не тільки теоретичні знання, а й навчити його виконувати наукові дослідження, які б завершувалися певним дослідницьким проектом. Під час практичної підготовки такі вміння виробляються внаслідок власних дій, при спостереженні за НДД досвідченого фахівця, а також при аналізі своєї діяльності, спільному обговоренні проблем у групі, 3 викладачем, супервізором, споживачами соціальних послуг (у формі рефлексивного діалогу). У результаті в студентів формується здатність до оперативної рефлексії як уміння осмислювати зміст дослідницьких дій. 
Цей вид підготовки (практика) визначається як період, протягом якого студенти мають можливість зрозуміти взаємозв'язок досліджень 3 їхньою майбутньою діяльністю, набути вміння вибудовувати зв'язки між експериментальною діяльністю і практичною роботою. Як підкреслює М. Бомбік, представники соціальних агентств, які є інструкторами практики, повинні бути підготовленими до виконання ролі наставника 3 проблем досліджень, що супроводжують адміністративну діяльність агентства і процес надання клієнтам соціальних послуг (Бомбик, 1996, с. 100).

При підготовці бакалаврів в університетах США практика вирізняється загальним характером. На рівні магістратури підхід до ії організації дещо інший: кожна програма формується відповідно до певної соціальної проблеми. До змісту курсів 3 практики соціальної роботи входять теорія, дослідження і досвід, накопичений у практиці соціальної роботи.

Аналіз процесу науково-дослідницької підготовки студентів у США показує, що найбільшого поширення набули такі методи навчання: аналіз методів і технік 3 позиції ї дослідницького потенціалу, моделювання, навчання в природних умовах, інструктаж, читання лекцій за певною тематикою (під керівництвом викладача), виконання завдань у команді, робота над груповим проектом, кураторство як індивідуальна взаємодія з супервізором, поєднання методу імітації і «живої» практики, ігрові методи.

Прикладом застосування ігрових методів є гра «Практика соціальної роботи», яка передбачає створення «географічної карти соціальної роботи». При цьому виділяють основні елементи, які формують «територію» досліджуваного простору (проблеми, клієнтське коло, інфраструктура соціальних закладів та ін.). У дискусіях, мета яких - пошук таких елементів, беруть участь викладачі, педагоги-наставники, студенти, керівники соціальних агентств.

До провідних засобів навчання, які використовуються факультетами соціальної роботи при навчанні студентів НДД, належать аудіозаписи, слайди, кіно, комп'ютер, Інтернет, щоденники, листи, звіти, протоколи та ін. Варто відзначити широке використання різних видів наукових джерел (довідників, підручників, наукових звітів, професійних періодичних видань та ін.), що відображені в переліку обов'язкової та додаткової літератури до кожного навчального курсу. Так, у процесі роботи над курсом «Поведінка людини i соціальне оточення» кожний студент в обов'язковому порядку виконує порівняльний аналіз якої-небудь концепції, аналізуючи через призму її бачення одну із соціальних проблем (бідність, насильство, расизм та ін.); готує 2-3 письмових есе 3 обраних тем (для цього необхідно вибрати із запропонованого списку літератури по два джерела наукового й дослідницького характеру); кілька разів студент повинен виступити 3 усним повідомленням, у якому потрібно 
представити результати критичного аналізу наукових джерел (заохочується порівняння думок учених і практичних соціальних працівників). Подібні вимоги ставляться і до всіх інших предметів, що входять до навчального плану підготовки соціальних працівників. У результаті студенти 3 першого семестру привчаються працювати з різними видами джерел, вчаться критично мислити, аналізувати, порівнювати, формулювати власну позицію щодо поширених або мало вивчених теорій соціальної роботи, викладати її грамотно і аргументовано.

Обов'язковою умовою для реалізації науково-дослідницької підготовки студентів є дослідницька культура викладачів. Педагог допомагає в корегуванні теми дослідження, формулюванні проблеми, визначенні вибірок, розробці й використанні методів збору і аналізу даних, написанні звіту. Так, М. Бомбік підкреслює: «Студенти вчаться на прикладах. Викладачі своєю поведінкою повинні демонструвати професійну прихильність до науково-дослідницької роботи. Процес знайомства 3 різними методами, демонстрація тісного зв'язку досліджень і практики допоможуть студентам глибше усвідомити важливість включення наукових методів у практику соціальної роботи» (Бомбик, 1996, с. 102).

Незважаючи на значний досвід зарубіжних університетів 3 досліджуваної проблеми, викладачі виділяють низку труднощів, які виникають при плануванні й реалізації підготовки студентів до НДД. Найбільш поширеними є: визначення цілей навчальних дослідницьких курсів, їхньої тематики; відпрацьовування методів викладання цих курсів; розробка критеріїв досягнень студентів, які працюють над дослідницькими проектами; забезпечення взаємозв'язку дослідницького курсу з іншими, особливо базовими дисциплінами навчального плану; зниження супротиву студентів до вивчення дослідницьких курсів (Goldstein, 2007).

Для подолання зазначених труднощів дослідники рекомендують планувати ці дисципліни таким чином, щоб методи досліджень сприймалися як невід'ємна частина фахової соціальної роботи. Викладачам, які ведуть дослідницькі дисципліни, рекомендується активніше використовувати рольові ігри, у яких студенти могли б здобувати певні навички досліджень, причому теми для них слід брати з практики .

Отже, академічна підготовка майбутніх соціальних працівників до НДД у зарубіжній вищій школі передбачає наявність вагомої теоретичної підготовки, а також введення студентів у технології самостійного здобуття нових професійних знань і навчання їх основам проведення наукових досліджень у проблемному полі соціальної роботи. 


\section{Висновки}

Здійснений аналіз професійної підготовки соціальних працівників до НДД у вищій школі США дозволяс виділити низку характерних для неї тенденцій, які варто враховувати в процесі аналогічної підготовки фахівців в Україні: фундаменталізація фахової підготовки соціальних працівників до НДД, що виражається, зокрема, у посиленні наукового базису професії через включення в освітні програми значного обсягу теоретичних дисциплін, завдань з елементами досліджень і залучення до викладацької діяльності висококваліфікованих фахівців, безпосередньо включених у дослідницький процес; забезпечення дослідницької спрямованості навчальних курсів на вирішення потреб практики, що реалізується через упровадження в навчальні плани значної кількості годин практики в соціальних агентствах, яка забезпечує «дослідницький простір» для роботи студентів. Включення дослідницької складової в процес підготовки майбутніх соціальних працівників в університетах США розглядається як спосіб підвищення рівня якості соціальної освіти. А вона, в свою чергу, дозволяє більш ефективно вирішувати ті завдання, які суспільство відносить до компетенції соціальних працівників.

Перспективами подальших досліджень вбачаємо вивчення американського досвіду з організації спільної діяльності ЗВО та соціальних закладів і служб щодо проведення наукових досліджень, активізації i вдосконалення системи професійної підготовки й підвищення рівня дослідницької культури соціальних працівників-практиків.

\section{Література}

Ben-David, J. (2002). Centers of Learning: Britain, France, Germany, United States. Piscataway: Transaction Publishers.

Бомбик, М. (1996). Подготовка к исследованиям в области социальной paботы. Обучение социальной работе: Преемственность и инновации. Ш. Рамон, Р. Сари (Ред). Москва: Аспект Пресс. С. 94-107.

Дьячек, Т. П. (2002). Подготовка социальных работников к исследовательской деятельности: теория и практика. Тамбов: изд-во ТГУ.

Goldstein, E. G. (2007). Social work education and clinical learning: Yesterday, today, and tomorrow. Clinical Social Work Journal, №35, C. 15-23. 


\title{
SCIENTIFIC RESEARCH PREPARATION OF FUTURE SPECIALISTS OF THE SOCIAL SPHERE AT THE UNIVERSITIES OF THE USA
}

Oksana Povidaichyk, Doctor of Pedagogical Sciences, Associate Professor at the Department of Sociology and Social Work, State University «Uzhhorod National University»

Nataliya Varga, Post graduate student, Department of General Pedagogic and Pedagogic of Higher School, State Higher Educational Establishment "Uzhhorod National University»

\begin{abstract}
The article reveals the peculiarities of preparation of specialists of the social sphere for scientific research activity in the high school of the United States. It has been proved that the structure of knowledge of scientific research activity of graduates of the university must include: a) general methodological and general scientific laws and principles; b) the provisions of scientific and cognitive activity and the methods of scientific research based on them; c) principles and methods of researches, applied in various spheres of social practice. Scientific research preparation is carried out in several forms: research blocks are included into the general and profile disciplines; in the framework of studying of the specialized courses; in the process of development of research projects; during the practice, an obligatory component of which is an independent research study. It has been found out that the experience of organizing and conducting of the researches is acquired by students in the framework of the study of discipline «Researches in social work». The discipline is aimed at familiarizing students with the research methodology, the specifics of working with scientific and professional literature, mastering the research methods as well as the peculiarities of developing of a research projects, the methods of data analysis and interpretation of the results of the study with a purpose of their practical application, writing a report on the work done. Scientific research preparation of students involves the use of such forms and methods as: work with the cases, modelling, training in the natural environment, instruction, teamwork, group project work, game techniques, writing essays. Typical trends of scientific research preparation in the high school of the US, which should be considered in Ukraine, are: fundamentalization of education, which is expressed in the strengthening of the scientific basis through the inclusion of theoretical courses and problems with the elements of research into the educational programs; involvement of qualified professionals into the teaching process; research
\end{abstract}


orientation of educational disciplines on solving the needs of practice, implemented through the introduction into the curriculum a significant number of hours of practice in social agencies providing «research space» for students.

Key words: professional preparation; specialists of the social sphere; scientific research activity; practice; US experience; forms and methods of scientific research preparation.

\section{References}

Ben-David, J. (2002). Centers of Learning: Britain, France, Germany, United States. Piscataway: Transaction Publishers.

Bombick, M. (1996). Preparation for researches in the sphere of social work. Social Work Education: Continuity and Innovations. S. Ramon, R. Sary (Ed.) Moscow: Aspect Press. P. 94-107. [in Russian].

Dyachek, T. P. (2002). Preparation of social workers for research activities: theory and practice. Tambov: TGU Publishing House. [in Russian].

Goldstein, E. G. (2007). Social work education and clinical learning: Yesterday, today, and tomorrow. Clinical Social Work Journal, 35, P. 15-23. 